\title{
Modeling the coherence of the financial system and economy of Russia
}

\author{
Valery V. Smirnov*, Vladislav L. Semenov, Anna N. Zakharova, Sergey B. Zimin, and Alena \\ $V$. Mulendeeva
}

Chuvash State University, Moskovsky prospect, 15, 428015 Cheboksary, Russia

\begin{abstract}
The article assesses the coherence of the financial system and economy of Russia, and also reveals the uncertainties in interrelation between the flow of finance and economic activity. The work reveals the possibilities of ensuring preservation of the form and content of economic system in the process of creating and using monetary funds. An analysis of the actual change of pace in the growth rate of finances and economic activity was carried out to eliminate the uncertainty of interrelation between the flow of finance and economic activity. In the result of the analysis, it was revealed that financial and economic measures are resorted to in order to eliminate uncertainty, and thereby, to ensure the preservation of coherence of the financial system of the modern Russian economy. Financial measures include an increase in gold reserves and monetary base; economic measures include an increase in the production of crude oil and natural gas and petroleum (associated) gas, extraction and dressing of iron ores. As a result of modeling the dynamics of the financial and economic systems with application of the modified Cobb-Douglas formula it is revealed that the financial system actively follows the dynamics of the economic system and there is sufficient compensating reaction of the former.Coherence of the Russian financial system and economy determines the capability and ability to maintain the form and content of the Russian economy with the help of finance. Elimination of the uncertainty of interrelation between the flow of finance and economic activity is confirmed by active following of the Russian financial system in path of the economic system dynamics and compensating reaction of the financial system.
\end{abstract}

\section{Introduction}

Relevance of the study of the financial system coherence in modern Russian economy is associated with the increasing global uncertainty of the finances role in stabilizing the world economy growth rates and eliminating crisis manifestations. In the current world economic activity, doubt is thrown upon the essence of finance as a set of economic relations in the process of creating and using monetary funds applied to ensure preservation of the economic system structure.

\footnotetext{
*Corresponding author: walera712006@mail.ru
} 
Consequently, study of the process of economic system structure preservation as a way to maintain the form and content of the Russian economy with the help of finance acquires status of a world problem. September 1, 2013 Central Bank of the Russian Federation received a status of mega-regulator what sharpens the problem and brings an everyday function of organized systems to the agenda-setting status. By acquiring the status of the procedural successor of the Federal Service for Financial Markets (the body eliminated on September 1, 2013 with its authorities transferred to the Central Bank) in the courts of general jurisdiction, magistrates' courts and arbitration courts, the Central Bank gets under its control the procedures related to the performance of state functions and the provision of state services.

In economic theory, the financial system is considered as a form of organization of monetary relations between economic entities. The issue of the coherence of the financial system with the economic one is related to the financial management effectiveness that is to maintain the form and content of the complex of economic relations in the process of creation and application of monetary funds for the structure preservation, support of the mode of activity, implementation of the program and achievement of the economic system goals.

For example, governments of Japan and India see financial development as a tool to stimulate economic growth, while economic growth is seen as a mechanism to promote financial development for sustainability. The Chinese government can establish proper rules in the financial market. In addition, the government can monitor the efficiency of lending to state-owned enterprises and study the process of financial resources transition from the input stage to the output stage in order to increase financial efficiency and thereby make a significant contribution to economic growth [1].

Economic theory recognizes the existence of an inverse U-shaped relationship between finance and economic growth in the long term. The results show that there is a threshold effect of the relationship between finance and growth, estimated at 142\% of GDP. Exceeding this threshold will not contribute to economic growth, since too much funding is detrimental $[2]$.

Worldwide practical experience in organizing monetary relations highlights accumulated risks of the financial system in emerging market economies. The Financial Vulnerability Index combines 32 indicators around the four following poles: (1) assessment and risk appetite; (2) imbalances in the non-financial sector; (3) financial sector vulnerability; and (4) global vulnerability [3].

Options to reduce financial vulnerability are determined by differences in financial policy as complexes of measures for accumulation, distribution and use of financial resources for the government to carry out its functions. At the same time, sources of bank financing, both internal and external, are imperfect substitutes. The shock comes from expanding domestic credit and activity, prices pressure on asset and real prices increase. The optimal credit-based redundancy rule (minimization of the compound function of losses) helps to mitigate both macroeconomic and financial instability as a measure based on credit-to-output, capital-tooutput and interest spreads, and real asset prices [4].

The unwinding spiral of prices for loans and assets creates a financial accelerator that works at the expense of investments in business sector [5]. Interaction between financial development and effective governance over entrepreneurship is increasing, namely: (1) there is an unconditional positive (negative) impact of financial development on formal (informal) entrepreneurship; (2) the conditional influence of governance quality increases formal entrepreneurship and decreases informal entrepreneurship; (3) net implications for formal entrepreneurship from the interaction of financial development with governance quality indicators are mostly positive, showing that governance quality can be used to enhance the positive impact of financial development on formal entrepreneurship; (4) net 
impacts on informal entrepreneurship due to the interaction between financial regulation and governance quality indicators are negative for most valuation models, suggesting that good governance can be used as a policy variable that improves the potentially weak impact of financial development on scaling back of the informal entrepreneurship [6].

In these conditions, the complementarity of bank and market financing is actively growing. The bank credit positive effect on growth is more evident in the stock markets [7].

Exchange-traded funds (ETFs) are one of the fastest growing categories of innovative financial products that have been introduced to many financial markets in both developing and developed countries. Among the many factors that potentially affect the spread of ETFs, the following stand out: stock market turnover, financial development and financial markets [8]

Over the past two decades, a growing presence of foreign banks has been observed in a number of emerging market and developing economies (EMDEs) taking financial liberalization measures. The presence of foreign banks helps to ease the credit constraints of companies, and firms with audited financial statements experience a decrease in credit constraints [9].

It should be noted that the link between financial liberalization and the banking crisis depends on the number of years since the last regulatory reforms. Regulations updating indirectly affects the banking crisis in accordance with the level of financial liberalization. However, the destabilizing effect of financial liberalization in developing countries cannot be offset by regulations update and becomes increasingly evident as regulations age [10].

Soviet period data show that public debt was increasing, inefficient financial assets accumulated in the household sector, and inefficient real assets accumulated in the enterprise sector. Funds flowing into the economy made an ineffective contribution to economic growth throughout almost the entire Soviet period. Funds continued to be wasted, non-performing financial assets accumulated, and, accordingly, the ruble value decreased. In this sense, Soviet monetary management was ineffective [11].

This led to the negative consequences of financial liberalization expressed in income inequality. Financial liberalization did not lead to a reduction in external borrowing costs; on the contrary, it had a favorable effect on the growth of foreign investment in the financial sector, further increasing the income inequality [12].

The existing financial system, due to objective market parameters, generates the prerequisites for curbing the processes of the formation of innovative reproduction. This is facilitated by the insignificant influence of natural resources on financial recovery and the absence of an insurance system for financial protection of the interests of population and business [13].

In Russian reality, regulatory standards are becoming an effective instrument for ensuring financial liberalization. Macroprudential policy is firmly established as the direction of Russian financial policy aimed at preventing excessive risk taking in the financial sector and mitigating its consequences for the real sector of the economy.

However, macroprudential policy faces a number of challenges related to its political sensitivity and institutional context. Weaker political positions are characteristic of countries where banking systems depend on domestic banks, while the opposite is observed for financial systems with significant market shares of other financial intermediaries. On the whole, political decisions regarding macroprudential policy should be associated with improving financial integration in order to stabilize the real sector of the economy [14]. 


\section{Methods}

To assess and model the coherence of the financial system and economy of Russia, we will use descriptive statistics methods, which include processing of empirical data, systematization, visual representation in the form of graphs and tables, their quantitative description by means of basic statistical indicators. The behavior of each variable is described using tables, charts, and summary measures. Tables, charts and graphs are built using MS Excel, IBM SPSS Statistics Software. Descriptive statistics evaluate a dataset based on statistical metrics. Statistical analysis will act as a method for collecting, studying and presenting large amounts of data by characteristics and relationships of data, correlation relationships of spatial and time series of indicators, while maintaining the research methodology.

\section{Results and Discussion}

The answer to the question of coherence of the financial system and economy of Russia requires clarification of the uncertainties in interrelation between the flow of finance and economic activity. The explanation is based on the real change in the growth rate of finance (The United Nations Statistics Division) and economic activity (OKVED 2, the Russian National Classifier of Types of Economic Activity) (Federal State Statistics Service).

As a result of assessing the growth rates of finance, leading positions were revealed (high median values, low variance and distribution asymmetry relative to the average) (Table 1) in gold reserves $\left(\mathrm{Me}=14.013 \% ; \sigma^{2}=20.325\right.$; distribution asymmetry relative to the average $=$ $0.197)$ and money supply: monetary base $\left(\mathrm{Me}=7.739 \% ; \sigma^{2}=78.585\right.$; distribution asymmetry relative to the average $=0.849$ ).

Table 1. The hierarchy of indicators rates of gain finance on the median values (Me, \%), 2010-2019

\begin{tabular}{|c|c|c|c|}
\hline Index & $\underset{\%}{\mathrm{Me}}$ & $\sigma^{2}$ & $\begin{array}{c}\text { Distribution } \\
\text { asymmetry } \\
\text { relative to the } \\
\text { average } \\
\end{array}$ \\
\hline Gold reserves (million troy ounces by the end of the period) & 14.013 & 20.325 & 0.197 \\
\hline $\begin{array}{l}\text { Money supply: broad monetary liabilities (billions of national currency } \\
\text { units by the end of the period) }\end{array}$ & 13.722 & 60.052 & -0.388 \\
\hline Stock price indices, $2010=100$ & 8.695 & 448.624 & 1.443 \\
\hline $\begin{array}{l}\text { Money supply: monetary base (billions of national currency units by the } \\
\text { end of the period) }\end{array}$ & 7.739 & 78.585 & 0.849 \\
\hline $\begin{array}{l}\text { International reserves minus gold: position in IMF (millions } \\
\text { of US dollars by the end of the period) }\end{array}$ & 6.801 & 1601.374 & 2.050 \\
\hline Short-term interest rates: money market rates (percentage per annum) & 6.015 & 1214.656 & -0.484 \\
\hline $\begin{array}{c}\text { International reserves minus gold: total (millions of US dollars by the end } \\
\text { of the period) }\end{array}$ & 4.401 & 151.148 & -1.502 \\
\hline $\begin{array}{l}\text { International reserves minus gold: in foreign currency (millions of US } \\
\text { dollars by the end of the period) }\end{array}$ & 4.290 & 155.829 & -1.512 \\
\hline Exchange rate (national currency per US dollar by the end of the period) & 3.218 & 673.115 & 1.695 \\
\hline Government bonds interest rate (annual interest at the end of the period) & -0.887 & 288.173 & 0.804 \\
\hline $\begin{array}{c}\text { International reserves minus gold: SDR (millions of US dollar by the end } \\
\text { of the period) }\end{array}$ & -0.986 & 38.604 & -1.647 \\
\hline
\end{tabular}

Source: calculated in "SPSS Statistics" based to the United Nations Statistics Division. Monthly Bulletin of Statistics Online. https://unstats.un.org/unsd/mbs/app/DataSearchTable.aspx (2020/12/25).

Low positions of the Russian financial system by SDR (Special Drawing Rights - special drawing rights - an artificial only cashless reserve and payment means, issued by IMF in the form of entries on bank accounts) $(\mathrm{Me}=-0.986 \%$; $62=38.604$; distribution asymmetry relative to the average $=1,647$ ) are caused by increased sanctions pressure from the United 
States and the leading EU countries against the backdrop of a deteriorating situation for energy commodities and a slowdown in world trade.

So, the sources of self-movement of the Russian financial system are the stable growth rates of gold reserves and monetary base. The negative point is the fact that the basis of this self-movement is the growth in the cost of SDR for Russia and, thus, the need to increase the volume of international reserves. On the other hand, the positive moment is the rise in the value of shares and a decrease in government bonds interest rate.

As a result of assessing the growth rates of OKVED 2 (NACE Rev. 2), leading positions (high median values) were revealed (Table 2) which are production of pharmaceutical substances $(\mathrm{Me}=21.6 \%)$; production of railway locomotives and rolling stock $(\mathrm{Me}=$ $21.5 \%)$; cutting, processing and finishing of stone $(\mathrm{Me}=18.75 \%)$; production of pesticides and other agrochemical products $(\mathrm{Me}=13.15 \%)$; provision of services in the field of mineral extraction $(\mathrm{Me}=12.7 \%)$; production of medicines and medical purpose materials $(\mathrm{Me}=$ $10.6 \%$ ), and production of musical instruments $(\mathrm{Me}=10.05 \%)$. Low OKVED 2 (NACE Rev.2) positions are with agglomeration of coal, anthracite and brown coal (lignite) and thermocoals production $(\mathrm{Me}=-38.75 \%)$; copying of recorded information carriers $(\mathrm{Me}=-$ $15.95 \%$ ); provision of services in the field of elimination of the consequences of pollution and other services related to waste disposal $(\mathrm{Me}=-10.2 \%)$.

Table 2. The hierarchy of the pace of growth indicators median values Russian Classification of Economic Activities 2 (NACE Red.2) (base 2010), 2010 - 2019

\begin{tabular}{|c|c|c|c|}
\hline Activity Type & Мe, \% & $\mathbf{6}^{2}$ & $\begin{array}{c}\text { Distribution } \\
\text { asymmetry } \\
\text { relative to the } \\
\text { average }\end{array}$ \\
\hline Production of pharmaceutical substances & 21.600 & 447.070 & 1.345 \\
\hline Production of railway locomotives and rolling stock & 21.500 & 742.103 & -0.800 \\
\hline Cutting, processing and finishing of stone & 18.750 & 2366.366 & 1.927 \\
\hline Production of pesticides and other agrochemical products & 13.150 & 626.187 & 1.670 \\
\hline Provision of services in the field of mineral extraction & 12.700 & 37.615 & -1.587 \\
\hline Production of medicines and medical purpose materials & 10.600 & 125.563 & -0.196 \\
\hline Production of musical instruments & 10.050 & 2943.510 & 2.063 \\
\hline $\begin{array}{l}\text { Collection, processing and disposal of waste; processing of } \\
\text { secondary raw materials }\end{array}$ & 9.650 & 140.870 & -1.822 \\
\hline & & & . \\
\hline Casting of metals & -5.000 & 447.207 & 0.680 \\
\hline Manufacture of tobacco goods & -6.050 & 97.835 & -1.149 \\
\hline Manufacture of furs & -7.050 & 226.843 & -1.180 \\
\hline Manufacture of electric lamps and lighting equipment & -7.050 & 236.439 & 0.243 \\
\hline Preparation and spinning of textile fibers & -7.800 & 47.030 & 0.187 \\
\hline $\begin{array}{l}\text { Manufacture of vehicles and equipment, not included in other } \\
\text { categories }\end{array}$ & -8.100 & 627.334 & -0.046 \\
\hline $\begin{array}{c}\text { Provision of services in the field of elimination of the consequences } \\
\text { of pollution and other services related to waste disposal }\end{array}$ & -10.200 & 21.072 & 0.933 \\
\hline Copying of recorded information carriers & -15.950 & 619.543 & 0.006 \\
\hline $\begin{array}{l}\text { Agglomeration of coal, anthracite and brown coal (lignite) and } \\
\text { thermocoals production }\end{array}$ & -38.750 & 1371.406 & 0.230 \\
\hline
\end{tabular}

Source: calculated in "SPSS Statistics" based by Russian Classification of Economic Activities 2 (NACE Red.2) (base 2010), the Federal State Statistics Service (Rosstat) (2020/12/25).

The most stable positive dynamics according to OKVED 2 (NACE Rev. 2) was revealed in production, transmission and distribution of electricity $\left(\sigma^{2}=0.547 ; \mathrm{Me}=1.3 \%\right)$; food production $\left(\sigma^{2}=0.736 ; \mathrm{Me}=4.9 \%\right)$; mining and dressing of iron ores $\left(\sigma^{2}=0.848 ; \mathrm{Me}=\right.$ $0.65 \%)$; production of crude oil and petroleum (associated) gas $\left(\sigma^{2}=0.895\right.$; $\left.\mathrm{Me}=0.8 \%\right)$; production of crude oil and natural gas $\left(\sigma^{2}=1.227 ; \mathrm{Me}=1.25 \%\right)$. It should be noted that the values of the distribution asymmetry relative to the average by growth rate for production, 
transmission and distribution of electricity, and food production are as low in the negative zone as -0.495 and -1.120 , respectively. This is due to inability of a relevant industry to quickly respond to market changes.

So, the sources of self-movement of the economic system are stable, but low growth rates of extraction and dressing of iron ores, production of crude oil and petroleum (associated) gas and natural gas, as well as opportunistic one, such as production, transmission and distribution of electricity, and food production.

The local economic drivers are production of pharmaceutical substances, production of railway locomotives and rolling stock, production of pesticides and other agrochemical products, provision of services in the field of mineral extraction. Agglomeration of coal, anthracite and brown coal (lignite) and thermocoals production are a burden on the Russian economy.

\section{Modeling}

To model the coherence of the financial system of the modern Russian economy, we will apply the Cobb-Douglas function as a basis, but having altered it by taking into account the following priorities - financial system - stable growth rates of gold reserves and economic system - the production of crude oil and natural gas.

Modeling the dynamics of financial and economic systems is according to the formula:

Dynamics $(\alpha><\beta)=\frac{R G L(t)+R G K(t)}{2} \cdot f\left(R G L(t)^{\alpha}\right) \cdot f\left(R G K(t)^{\beta}\right)$

where $R G L(t)$ denotes growth rates for extraction of crude oil and natural gas; $R G K(t)$ denotes growth rates for gold reserves; $f\left(R G L(t)^{\alpha}\right)=-1.5133 \cdot R G L(t)+19.332$ и $f\left(R G K(t)^{\beta}=0.2669 \cdot R G K(t)^{1.1249}\right.$ denotes approximation functions (trend), $\alpha$ and $\beta$ denote the corresponding elasticity coefficient.

Modeling of coherence of the financial system of the modern Russian economy is according to the following formulas:

Appropriate $(\alpha>\beta)=$ Dynamics $(\alpha>\beta) /$ Dynamics $(\alpha<\beta)$ и

Appropriate $(\alpha<\beta)=$ Dynamics $(\alpha<\beta) /$ Dynamics $(\alpha>\beta)$

As a result of modeling the dynamics of financial and economic systems, a positive moment was revealed with $\alpha<\beta$, i.e. growth rate of the economic system $(\mathrm{Me}=221.00 \%)$ is higher than that for the financial one $(\mathrm{Me}=-28.78 \%)$. At the same time, volatility and spread of indicators of the economic system $\left(\sigma^{2}=1415407.80\right.$; distribution asymmetry relative to the average $=1.18)$ are higher than those for the financial one $\left(\sigma^{2}=14497.97\right.$; distribution asymmetry relative to the average $=-0.38$ ).

So, the economic system dynamics volatility is compensated by the financial system. At the same time, the economic system is unable to compensate for the volatility of the financial system $[15,16]$.

As a result of modeling the coherence of the financial system in the modern Russian economy, it was confirmed that the financial system actively follows the dynamics of the economic system Appropriate $(\alpha<\beta)$ (Figure 2) $-\mathrm{y}=0.9412 \mathrm{x}^{5}-15.602 \mathrm{x}^{4}+96.779 \mathrm{x}^{3}-$ $277.1 \mathrm{x}^{2}+358.38 \mathrm{x}-163.74 ; \mathrm{R}^{2}=1$. 


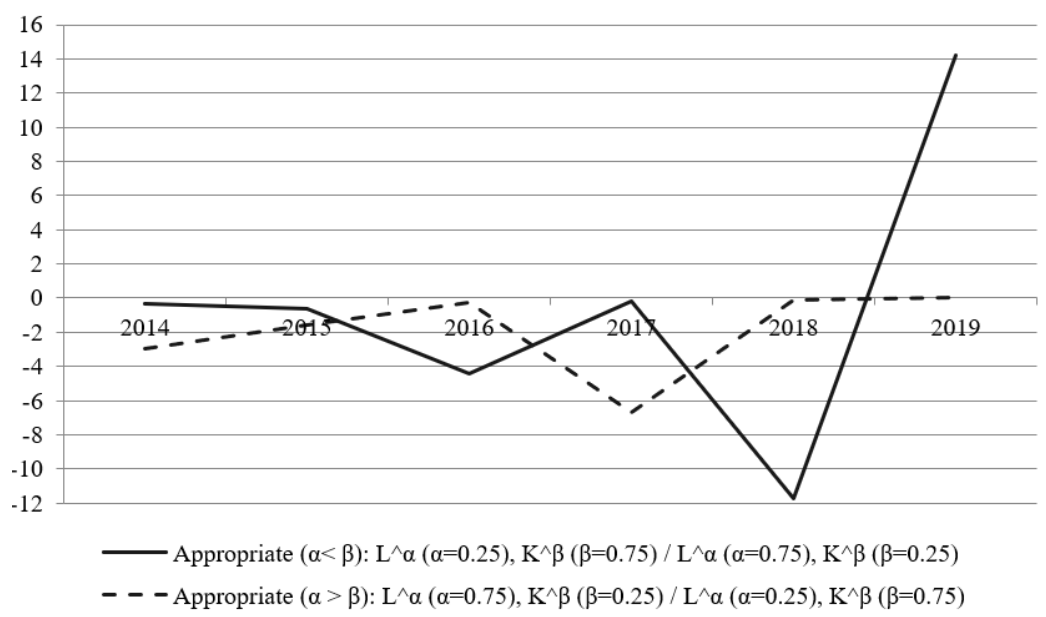

Fig. 2 Modeling the compliance of the financial system with the modern Russian economy.

Source: calculated using the Cobb-Douglas function «SPSS Statistics» according to United Nations Statistics Division. Monthly Bulletin of Statistics Online. https://unstats.un.org/unsd/mbs/app/DataSearchTable.aspx $(25$ March 2020) and by Russian Classification of Economic Activities 2 (NACE Red.2) data (base 2010), the Federal State Statistics Service (Rosstat) (2020/12/25).

In the result of the analysis of coherence of the modern Russian economy financial system, the following moments of interaction were identified:

- positive, which for financial system includes stable growth rates of gold reserves and monetary base; for economic system this includes stable growth rates in production of crude oil and natural gas and petroleum (associated) gas, mining and dressing of iron ores; for market growth this includes production, transmission and distribution of electricity and food production, for local growth this includes production of pharmaceutical substances, production of railway locomotives and rolling stock, production of pesticides and other agrochemical products, provision of services in the field of mineral extraction;

- negative, which for financial system includes an increase in the value of SDR and an increase in the volume of international reserves; for economic system this includes agglomeration of coal, anthracite and brown coal (lignite) and the production of thermal coals.

The result of modeling the coherence of the financial system in the modern Russian economy reflected that the financial system actively follows the economic system, as well as its compensating reaction [17].

At the same time, the raw material profile of the Russian economy significantly affects the dynamics of the financial system $\left(y=0.9412 x^{5}-15.602 x^{4}+96.779 x^{3}-277.1 x^{2}+\right.$ $358.38 \mathrm{x}-163.74 ; \mathrm{R}^{2}=1$ ), and not vice versa, so the economic system is unable to compensate for the financial system volatility.

Moreover, with the formation of the Russian economy management system, the financial system function, to a greater extent, manifests itself in the feedback. In this respect, the Central Bank, by definition, cannot be a mega-regulator.

\section{Conclusions}

The issue of coherence of the financial system in the modern Russian economy is related to the essence of finance as a set of economic relations in the process of creating and using monetary funds applied to ensure preservation of the economic system structure. Process of 
economic system structure preservation is a way to maintain the form and content of the Russian economy with the help of finance. The problem of coherence of the modern Russian economy financial system is in the sphere of uncertainty about the interrelation between the finances flow and economic activity.

An analysis of the actual change in the growth rate of finance and economic activity was carried out (OKVED 2) to eliminate the uncertainty. In the result of the analysis, it was revealed that financial and economic measures are resorted to in order to eliminate uncertainty, and thereby, to ensure the preservation of coherence of the financial system of the modern Russian economy.

Financial measures include building up gold reserves and monetary base. The negative aspect of these measures is the increase in the SDR value and the need to increase the volume of international reserves, and the positive aspect is the increase in the value of shares and a decrease in the interest rate on government bonds.

Economic measures include an increase in production of crude oil and natural gas and petroleum (associated) gas; extraction and dressing of iron ores; as well as opportunistic ones of production, transmission and distribution of electricity, and production of food products.

As a result of modeling the dynamics of financial and economic systems using the modified Cobb-Douglas formula, it was revealed that growth rates of the economic system, its volatility, spread of indicators and distribution asymmetry relative to the average are higher than those of the financial one. Moreover, the economic system dynamics volatility is compensated by the financial system. At the same time, volatility of the economic system is unable to compensate for the financial system.

So, the coherence of the financial system in the modern Russian economy is confirmed by the aspect that the financial system actively follows the dynamics of the economic system, as well as its compensating reaction, and not vice versa, the economic system is unable to compensate for the volatility of the financial system. In the global management system of the Russian economy, the function of the financial system is logically manifested in a feedback, thereby indicating that the Central Bank does not correspond to the mega-regulator status.

\section{References}

1. C.-F. Wu, S.-C. Huang, T. Chang, C.-C. Chiou, H.-P. Hsueh, Journal of Computational and Applied Mathematics, 372, 112660 (2020)

2. V. Swamy, M. Dharani, International Review of Economics \& Finance, 64, 122 (2019)

3. E. Lepers, A. S. Serrano, Research in International Business and Finance, 51, 101068 (2020)

4. P.-R. Agénor, K. Alper, L. Pereira da Silva, Journal of International Money and Finance, 8, 23 (2018)

5. A. Benedictow, R. Hammersland, Economic Systems, 44(1), 100731 (2020)

6. A. Omri, Journal of Business Research, 108, 277 (2020)

7. J. Botev, B. Égert, F. Jawadi, International Economics, 160, 3 (2019)

8. A. Marszk, E. Lechman, Journal of Macroeconomics, 62, 103064 (2019)

9. S. Gopalan, S. Sasidharan, Journal of Economics and Business, 107, 105861 (2020)

10. M. Hamdaoui, S. Maktouf, Structural Change and Economic Dynamics, 5, 184 (2020)

11. Y. Nakamura, Explorations in Economic History, 6, 65 (2017)

12. I. Erauskin, S. J. Turnovsky, Journal of International Economics, 119, 55 (2019)

13. F. Faisal, Y. Sulaiman, T. Tursoy, Resources Policy, 64, 101512 (2019) 
14. M. S. Rahman, F. Shahari, Research in International Business and Finance, 42, 1244 (2017)

15. V. V. Smirnov, V. L. Semenov, E. N. Kadyshev, T. V. Talanova, A. N. Zakharova, N. G. Gubanova, Contemporary Geo-Economic Conditions of Capitalism, Proceedings of the 35th International Business Information Management Association Conference (IBIMA). Education Excellence and Innovation Management: A 2025 Vision to Sustain Economic Development during Global Challenges, 3736 (2020)

16. V. V. Smirnov, V. L. Semenov, O. L. Taranova, T. V. Talanova, A. N. Zakharova, N. A. Ivanova, Analysis of Financial Solvency of BRICS and Shanghai Cooperation Organization Countries. Proceedings of the 35th International Business Information Management Association Conference (IBIMA), Education Excellence and Innovation Management: A 2025 Vision to Sustain Economic Development during Global Challenges, 3731 (2020)

17. V. V. Smirnov, A. N. Zakharova, T. V. Talanova, A. G. Abramova, S. A. Petunova, I. B. Getskina, M. N. Yaklashkin, The Problem of Youth Unemployment and Entrepreneurship. Proceedings of the 35th International Business Information Management Association Conference (IBIMA), Education Excellence and Innovation Management: A 2025 Vision to Sustain Economic Development during Global Challenges, 7741 (2020) 